\title{
PENGARUH KEMAMPUAN MENYUSUN RPP DAN SIKAP SOSIAL TERHADAP KETRAMPILAN MENGAJAR MAHASISWA DALAM PROGRAM PLP PGSD UNISSULA DI KECAMATAN GENUK
}

\author{
${ }^{1}$ Sari Yustiana ${ }^{2}$ Muhamad Afandi \\ ${ }^{1}$ sari.yustiana@unissula.ac.id ${ }^{2}$ mafandi@unissula.ac.id \\ ${ }^{1,2}$ Universitas Islam Sultan Agung
}

\begin{abstract}
ABSTRAK
Tujuan dari penelitian ini adalah untuk mengetahui pengaruh kemampuan menyusun RPP terhadap ketrampilan mengajar, mengetahui pengaruh sikap sosial terhadap ketrampilan mengajar, serta mengetahui pengaruh kemampuan menyusun RPP dan ketrampilan mengajar secara bersama- sama terhadap ketrampilan mengajar mahasiswa dalam program PLP PGSD Unissula di Kecamatan Genuk. Penelitian ini menggunakan pendekatan kuantitatif dengan metode expost facto. Populasi berjumlah 156 mahasiswa dengan sample 113 mahasiswa. Teknik pengambilan sample secara acak (proporsional random sampling) menggunakan tabel Krecjie \& Morgan dengan tingkat kesalahan $5 \%$. Analisis data yang digunakan adalah regresi linear tunggal dan regresi linear ganda. Variabel bebas pada penelitian ini adalah ketrampilan menyusun RPP $\left(\mathrm{X}_{1}\right)$ dan sikap sosial $\left(\mathrm{X}_{2}\right)$, sedangkan variabel terikatnya adalah ketrampilan mengajar (Y). Berdasarkan hasil penelitian disumpulkan bahwa data penelitian normal dengan koefisien 0,200>0,05. Data ketrampilan menyusun RPP linear dengan koefisien 0,989>0,05, dan data sikap sosial linear dengan koefisien 0,980>0,05. Uji hipotesis terhadap pengeruh X1 terhadap Y1 diperoleh nilai signifikansi sebesar $0,002<0,05$ yang berarto terdapat pengaruh positif dan signifikan. Uji hipotesis X2 terhadap Y1 diperoleh nilai signifikansi $0,011<0,05$ yang berarti terdapat pengaruh positif dan signifikan. Sedangkan hasil hipotesis pengaruh X1 dan X2 secara bersama-sama terhadap Y1 diperoleh nilai signifikansi X1 sebesar $0,031<0,05$ dan nilai signifikansi $X 2$ sebesar $0,006<0,05$ yang berarti keduanya berpengaruh signifikan.
\end{abstract}

Kata Kunci: RPP, sikap sosial, ketrampilan mengajar

PENDAHULUAN

Berdasarkan Peraturan Menteri

Pendidikan no 16 tahun 2007, guru yang berkualitas harus memiliki kompetensi pendidik.Kompetensi ini meliputi, pedagogik, kepribadian, sosial, dan profesional. Kompetensi pedagogik yang harus dimiliki guru salah satunya berkaitan dengan penyusunan Rencana Pelaksanaan pembelajaran (RPP). Selain sebagai pelengkap administrasi, RPP dibuat sebagai panduan guru dalam mengajar.Dengan adanya RPP sebagai panduan guru dalam mengajar, maka 
pembelajaran yang dilakukan oleh guru menjadi terarah dan sistematis. Hall ini seperti yang dikemukaan oleh Arthur at all (2006: 90) "by writing a short-term plan you are 'rehearsing' your lessons, anticipating challengers and working out exactly what you will do".

Pentingnya menyusun RPP ini sendiri berkaitan dengan tujuan-tujuan rencana pembelaran, seperti yang dikemukaan oleh Garth et.all (2016:2):

(1). Learning planning is the deliberative process a learner engages in to identify their learning needs, set time aside to acquire new knowledge or skill, and undertake activities which move them toward attaining their goal (2). Learning plans are a tool intended to assist learners to cohesively and strategically identify, plan and document their learning needs and activities; as well as to prompt reflection of their learning experiences and progress $(3,4)$. Learning plans and portfolios were introduced to promote a self-directed learning process and enable individuals to monitor their progress (5). Subsequently, the submission of a learning plan has become a common assessment requirement as evidence of both learning planning and of active engagement in learning activities. Internationally, learning plans and portofolios are a familiar activity for those engaged in general practice $(G P)$ training, forming part of the credentialing process.

Berdasarkan Peraturan Mentri Pendidikan no 22 tahun 2016 mengenai standar proses pendidikan dasar dan menengah, di dalam RPP terdapat identitas sekolah, identitas mata pelajaran, kelas/semester, materi pokok, alokasi waktu, tujuan pembelajaran, kompetensi dasar dan indicator pemcapaian kompetensi, materi pembelajaran, metode pembelajaran, media pembelajaran, sumber belajar, langkah-langkah pembelajaran, serta penilaian hasil belajar. Melihat pentingnya fungsi RPP, maka baik guru maupun calon guru hendaknya mampu menyusun RPP sesuai dengan standar.

Kompetensi lain yang harus dimiliki guru dan calon guru adalah kompetensi sosial. Kompetensi sosial berkaitan dengan sikap guru terhadap 
siswa maupun teman sejawat. Sikap tersebut mencakup sikap inklusif, tidak diskriminatif, dapat berkomunikasi secara efektif, dan adapat beradaptasi. Sehingga kompetensi ini berkaitan dengan hubungan guru atau calon guru dengan siswa, dan dengan teman sejawat. Sikap yang dimunculkan seseorang merupakan akibat dari pembelajaran yang telah dialami, hal ini dikemukaan oleh Simpson et.all (1976: 280) bahwa “...the feelings, attitudes, and values our student take from their science courses may be of more consequence-both immediately and ultimately-than anything else the curriculum embodies".

Selain kompetensi profesional, setiap guru dan calon guru juga harus menguasai ketrampilan dasar mengajar. Ketrampilan mengajar mahasiswa yang baik akan mempengaruhi kualitas pembelajaran yang dilakukan, hal ini seperti yang dikemukaan oleh Chapman and Adams (O'Sullivan 2005, p: 251) "improvement in the quality and, to some extent, the efficiency and equity of education depend on the nexus of teaching and learning".
Ketrampilan dasar mengajar meliputi ketrampilan bertanya, ketrampilan memberi penguatan, ketrampilan mengadakan variasi, keterampilan menjelaskan, ketrampilan membuka dan menutup pelajaran, ketrampilan membimbing diskusi kelompok kecil, ketrampilan mengelola kelas, dan ketrampilan mengajar kelompok kecil. Ketrampilan dasar mengajar penting dikuasai guru dan calon guru karena berkaitan dengan penguasaan kelas ketika mengajar. Jika guru mampu menguasai kelas dengan baik, maka rencana pembelajaran yang telah disusun juga dapat berjalan dengan baik, sehingga tujuan pembelajaran dapat tercapai.

Berdasarkan hasil observasi terhadap penyusunan RPP mahasiswa PGSD Unissula, mahasiswa masih menyusun berdasarkan contoh-contoh dari internet. Sehingga tidak sesuai dengan peraturan yang ada. Selain itu juga penyusunan RPP tidak disesuaikan dengan karakteristik peserta didik. Hal ini karena mahaiswa belum menguasai teknik penyusunan RPP dengan baik.

Berdasarkan hasil observasi, juga didapatkan masalah bahwa mahasiswa 
kurang menunjukkan kompetensi sosial dalam keseharian. Hal ini dapat dilihat dari kurangnya kerjasama antar mahasiswa. Selain itu, kemampuan komunikasi mahasiswa juga masih kurang. Ketika melakukan presentasi mahasiswa cenderung terpaku pada teks presentasi yang telah disusun. Selain itu, ketika menjawab pertanyaan lebih banyak mencari dari internet (smart phone), sehingga tidak menggambarkan pemahaman yang dimiliki.

Penyusunan RPP sebagai pedoman kegiatan pembelajaran serta kompetansi sosial mempengaruhi cara mahasiswa dalam praktek mengajar. Program praktek mengajar ini disebut Praktik Latihan profesi (PLP). Karena dalam program PLP mahasiswa dituntut untuk praktik membuat RPP dan mengajar, dengan penilaian dari praktisi langsung yaitu guru.

\section{METODE PENELITIAN}

Jenis penelitian ini menggunakan pendekatan kualitatif dengan jenis penelitian expost-facto,karena penelitian ini tidak dapat mengontrol variable independen. Populasi dalam penelitian ini yaitu semua mahasiswa PGSD Unissula semester VII yang mengikuti program PLP dengan jumlah 156 mahasiswa. Penentuan sampel penelitian ini diambil secara acak (proporsional random sampling). Semua anggota populasi mendapatkan kesempatan yanag sama untuk dijadikan sample, sedangkan teknik penentuan jumlah sample menggunakan tabel Krecjie \& Morgan dengan tingkat kesalahan 5\%. Dengan demikian jumlah sample dalam penelitian ini adalah 113.Penelitian ini mengkaji dua variabel. Variabel bebas (independen) yaitu kemampuan menyusun RPP $\left(\mathrm{X}_{1}\right)$ dan sikap sosial $\left(\mathrm{X}_{2}\right)$ dan variabel terikat (dependen) ketrampila mengajar (Y).

Cara memperoleh data yang dibutuhkan, dapat dilakukan dengan banyak cara. Dalam penelitian ini, teknik pengumpulan data yang digunakan adalah teknik nontes dengan menggunakan lembar observasi.Lembar observasi digunakan untuk mencari data kemampuan menyusun RPP, sikap sosial dan ketrampilan mengajar.Adapun pertimbangan penggunaan lembar observasi karena data yang diungkap merupakan data lampau yang telah terjadi 
dan data performansi mahasiswa.Data tersebut akan dinilai kesesuaiannya dengan indikator-idikator yang ada, yaitu indikator penyusunan RPP, indikator kompetensi sosial, dan indikator ketrampilan mengajar.

Setelah data diperoleh, tahap selanjutnya adalah melakukan analisis data.Analisis data yang digunakan dalam penelitian ini adalah teknik analisis regresi tunggal dan regresi ganda. Selain itu juga dilakukan analisis deskriptif yang berfungsi memberikan gambaran umum tentang data yang diperolah. Namun sebelum dilakukan analisis data hasil penelitian, terlebih dahulu data diuji kan prasyarat. Uji prasyarat yang dilakukan adalah uji normalitas menggunakan one sample kolmogorov-smirnov dengan menggunakan bantuan softwereSPSS versi 19.0.Data dinyatakan berdistribusi normal jika signifikansi lebih besar dari 0.05.Kemudian dilakukan uji linearitas menggunakan bantuan softwere SPSS versi 19.0 dengan melihat signifikansi deviation from linearity dari uji $\mathrm{F}$ linear.

\section{HASIL DAN PEMBAHASAN}

Sebelum dilakukan uji hipotesis terlebih dahulu dilakukan uji prasyarat analisis data. Uji prasyarat yang pertama adalah uji normalitas yang bertujuan untuk mendeteksi normal atau tidaknya data yang diperoleh. Adapun hasil uji normalitas adalah sebagai berikut:

Tabel 1 Normalitas Data

\begin{tabular}{|l|c|c|c|c|c|c|c|}
\hline & \multicolumn{3}{|c|}{$\begin{array}{l}\text { Kolmogorov- } \\
\text { Smirnov }\end{array}$} & \multicolumn{3}{|c|}{$\begin{array}{c}\text { Shapiro- } \\
\text { Wilk }\end{array}$} \\
\cline { 2 - 7 } & $\begin{array}{c}\text { Stati } \\
\text { stic }\end{array}$ & df & $\begin{array}{c}\text { Si } \\
\text { g. }\end{array}$ & $\begin{array}{c}\text { Stati } \\
\text { stic }\end{array}$ & df & $\begin{array}{c}\text { Si } \\
\text { g. }\end{array}$ \\
\hline Unstandar &, 055 & 1 &, 20 &, 988 & 1 &, 3 \\
dized & & 2 & $0^{*}$ & & 2 & 07 \\
Residual & & 7 & & & 7 & \\
\hline
\end{tabular}

a. Lilliefors Significance Correction

*. This is a lower bound of the true significance.

Uji normalitas pada data ketrampilan mengajar memperoleh sig $=$ $0,200>0,05 \quad(\alpha=5 \%=0,05)$, Но diterima. Dengan demikian dapat disimpulkan bahwa sampel ketrampilan mengajar berasal dari populasi berdistribusi normal.

Selaian uji normalitas, uji prasyarat juga menggunakan uji 
linearitas. Uji linearitas dilakukan untuk melihat linearitas data Kemampuan menyusun RPP terhadap Ketrampilan Mengajar dan linearitas data sikap social tergadap ketrampilan mengajar. Hasil perhitungan linearitas kemampuan menyusun RPP terhadap ketrampilan mengajar disajikan dalam tebel berikut:

Tabel 2 Uji Linieritas Kemampuan Menyusun RPP

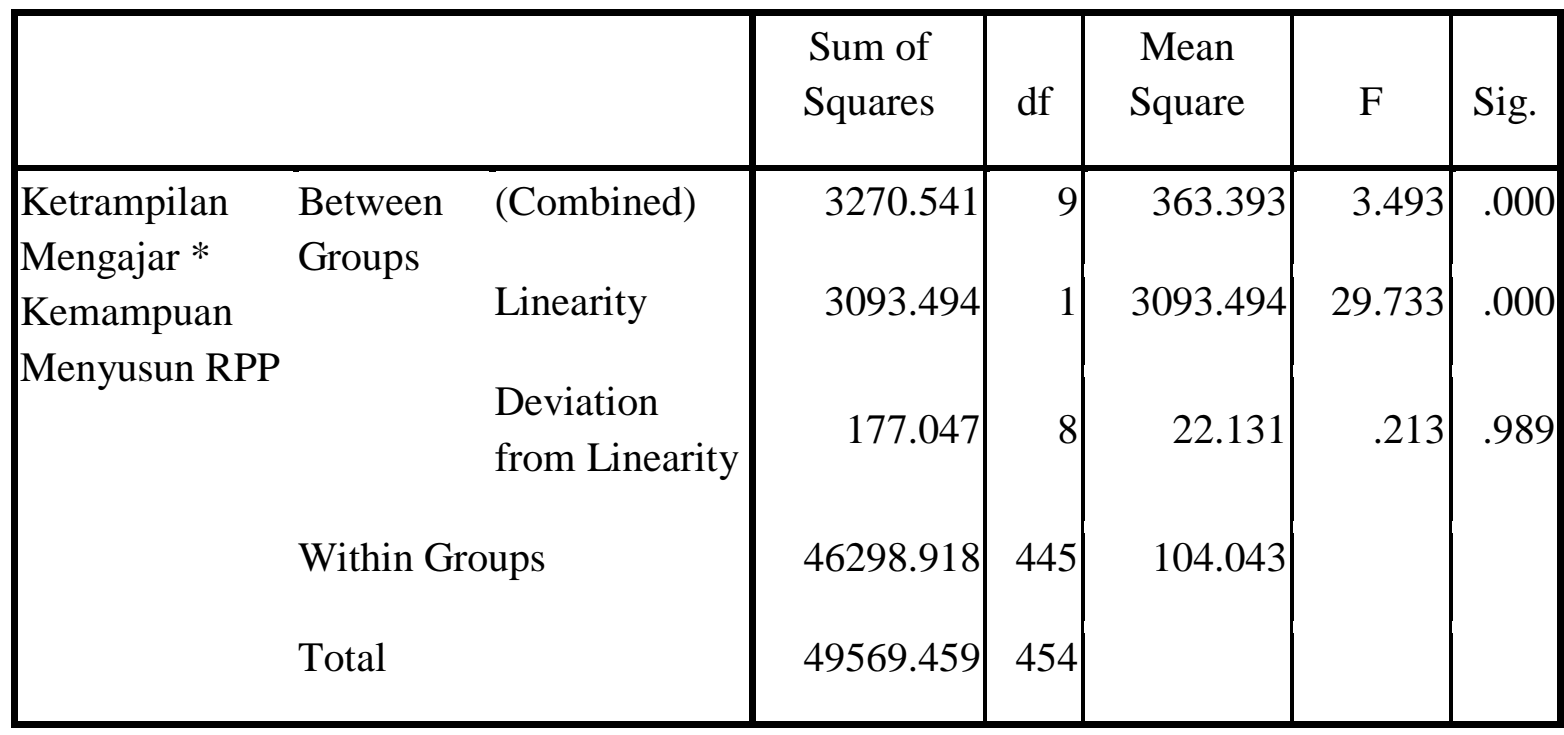

\section{Berdasarkan tebel di atas}

diperoleh nilai signifikansi sebesar 0,989 lebih besar dari 0,05 yang artinya terdapat hubungan linearitas signifikan antara variable kemampuan menyusun RPP (x1) dan ketrampilan mengajar (y).

Hasil perhitungan linearitas sikap sosial terhadap ketrampilan mengajar disajikan pada tabel berikut:

Tabel 3 Linearitas Sikap Sosial

\begin{tabular}{|c|c|c|c|c|c|c|c|}
\hline & & & $\begin{array}{l}\text { Sum of } \\
\text { Squares }\end{array}$ & $\mathrm{df}$ & $\begin{array}{l}\text { Mean } \\
\text { Square }\end{array}$ & $\mathrm{F}$ & Sig. \\
\hline \multirow{4}{*}{$\begin{array}{l}\text { Ketrampilan } \\
\text { Mengajar* } \\
\text { Sikap Sosial }\end{array}$} & Between & (Combined) & 3413.541 & 13 & 262.580 & 2.509 & .003 \\
\hline & Groups & & & & & & \\
\hline & & Linearity & 2980.521 & 1 & 2980.521 & 28.478 & .000 \\
\hline & & $\begin{array}{l}\text { Deviation } \\
\text { from Linearity }\end{array}$ & 433.020 & 12 & 36.085 & .345 & .980 \\
\hline
\end{tabular}




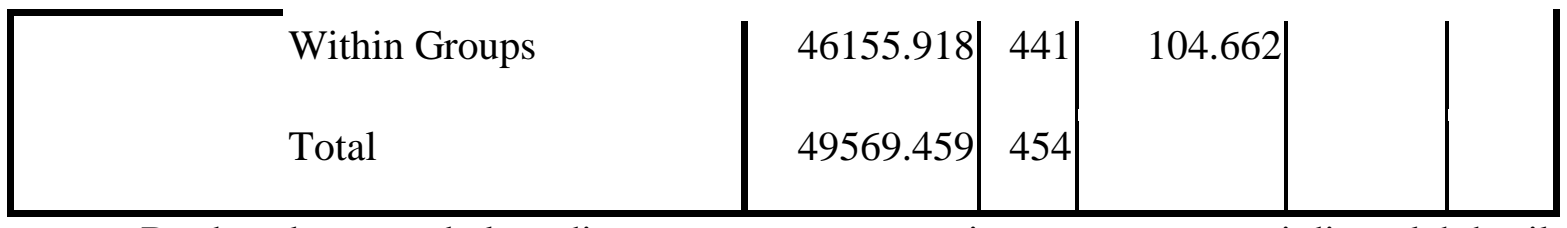

Berdasarkan tabel di atas

diperoleh nilai signifikansi sebesar 0,980

lebih besar dari 0,05 yang artinya terhadap hubungan linearitas signifikansi antara variabel sikap sosial (x2) dan terhadap ketrampilan mengajar (y).

Setelah diketahui data berdistribusi normal, dan data linear, selanjutnya dilakukan pengujian hipotesis data. Berdasarkan hasil perhitungan untuk mencari persamaan regresi diperoleh hasil dari output pertama besarnya nilai korelasi (R) antara kemampuan menyusun RPP (x1) dengan ketrampilan mengajar (y) sebesar $0,002<0,05$. Hal ini menunjukkan bahwa variabel kemampuan menyusun RPP berpengaruh positif signifikan terhadap ketrampilan mengajar. Hasil perhitungan tersebut dapat dibaca pada tabel berikut:

Tabel 4 Uji Regresi Kemampuan menyusun RPP terhadap Ketrampilan Mengajar

\begin{tabular}{|c|c|c|c|c|c|}
\hline \multirow[b]{2}{*}{ Model } & \multicolumn{2}{|c|}{$\begin{array}{c}\text { Unstandardized } \\
\text { Coefficients }\end{array}$} & \multirow[t]{2}{*}{$\begin{array}{l}\text { Standardized } \\
\text { Coefficients }\end{array}$} & \multirow[b]{2}{*}{$\mathrm{t}$} & \multirow[b]{2}{*}{ Sig. } \\
\hline & B & Std. Error & & & \\
\hline 1 (Constant) & 81,176 & 2,687 & & 30,215 & ,000 \\
\hline $\begin{array}{l}\text { Kemampuan Menyusun } \\
\text { RPP }\end{array}$ &, 101 & ,203 &, 044 & 4,495 & ,002 \\
\hline
\end{tabular}

a. Dependent Variable: ketrampilan mengajar

Berdasarkan hasil perhitungan untuk mencari persamaan regresi diperoleh hasil dari output. Besarnya nilai korelasi (R) antara sikap sosial (x2) dengan ketrampilan mengajar (y) sebesar
$0,011<0,05$. Ini berarti variabel sikap sosial berpengaruh positif signifikan terhadap ketrampilan mengajar. Hasil perhitungan tersebut dapat dilihat pada tabel berikut: 
Tabel 5 Uji Regresi Sikap Sosial Terhadap Ketrampilan Mengajar

\begin{tabular}{|c|c|c|c|c|c|}
\hline \multirow[b]{2}{*}{ Model } & \multicolumn{2}{|c|}{$\begin{array}{l}\text { Unstandardized } \\
\text { Coefficients }\end{array}$} & \multirow{2}{*}{$\frac{\text { Standardized Coefficients }}{\text { Beta }}$} & \multirow[b]{2}{*}{$\mathrm{t}$} & \multirow{2}{*}{ Sig. } \\
\hline & B & Std. Error & & & \\
\hline 1 (Constant) & 77,490 & 2,685 & & 28,863 & , 000 \\
\hline Sikap sosial & ,294 & ,155 & 167, & 1,893 & 011 \\
\hline
\end{tabular}

a. Dependent Variable: ketrampilan mengajar

Untuk mengukur pengaruh diuji dengan satistik regresi berganda. variabel kemampuan menyusun RPP (x1) Dengan bentuk persamaan regresi linear dan sikap sosial $(\mathrm{x} 2)$ secara bersama- berganda: $\mathrm{Y}=\mathrm{a}+\mathrm{bx} 1+\mathrm{cx} 2$. sama terhadap ketrampilan mengajar (y),

\section{Tabel 6 Uji koedisien Determinasi}

\begin{tabular}{|l|r|r|r|r|}
\hline Model & $\mathrm{R}$ & R Square & Adjusted R Square & $\begin{array}{c}\text { Std. Error of the } \\
\text { Estimate }\end{array}$ \\
\hline 1 &, $676^{\mathrm{a}}$ &, 531 &, 515 & 5,75879 \\
\hline
\end{tabular}

a. Predictors: (Constant), kemampuan menyusun RPP, sikap sosial

b. Dependent Variable: ketrampilan mengajar

Berdasarkan tabel di atas independen sekitar 51,5\%. Selanjutnya menunjukkan nilai Adjusted $\mathrm{R}$ sebesar ada atau tidaknya pengaruh variabel 0,515 atau 51,5\% berarti variabel tersebut dapat dilihat pada tabel berikut: dependen dapat dijelaskan oleh variabel 
Tabel 7 Uji F

\begin{tabular}{|c|c|c|c|c|c|}
\hline Model & Sum of Squares & df & $\begin{array}{l}\text { Mean } \\
\text { Square }\end{array}$ & $\mathrm{F}$ & Sig. \\
\hline Regression & 131,408 & 2 & 65,704 & 7,981 &, $002^{\mathrm{a}}$ \\
\hline Residual & 4112,293 & 124 & 33,164 & & \\
\hline Total & 4243,701 & 126 & & & \\
\hline
\end{tabular}

a. Predictors: (Constant), kemampuan menyusun RPP, sikap sosial

b. Dependent Variable: ketrampilan mengajar

Pada tabel di atas menunjukkan

Uji hipotesis secara bahwa $\mathrm{F}$ hitung sebesar 7,981 dan nilai bersama-sama antara $\mathrm{x} 1$ dan $\mathrm{x} 2$ signifikansi sebesar $0,002<0,05$. Hal ini menunjukkan bahwa variabel independen terhadap y dapat dilihat pada tabel berikut: berpengaruh terhadap variabel dependen.

Tabel 8 Uji Hipotesis Secara Bersama-sama

\begin{tabular}{|c|c|c|c|c|c|}
\hline \multirow[b]{2}{*}{ Model } & \multicolumn{2}{|c|}{$\begin{array}{c}\text { Unstandardized } \\
\text { Coefficients }\end{array}$} & \multirow{2}{*}{$\begin{array}{c}\text { Standardized } \\
\text { Coefficients } \\
\text { Beta }\end{array}$} & \multirow[b]{2}{*}{$\mathrm{t}$} & \multirow[b]{2}{*}{ Sig. } \\
\hline & B & Std. Error & & & \\
\hline (Constant) & 78,367 & 3,032 & & 25,850 & , 000 \\
\hline $\begin{array}{l}\text { Kemampuan } \\
\text { menyusun RPP }\end{array}$ & , 151 & 240 & ,066 & 3,628 & 031 \\
\hline Sikap sosial & 357 & 185 & 203 & 3,927 & ,006 \\
\hline
\end{tabular}

a. Dependent Variable: ketrampilan mengajar 
Secara bersama-sama kemampuan menyusun RPP dan sikap sosial berpengaruh terhadap ketrampilan mengajar. Hal ini dibuktikan dengan nilai signifikansi kemampuan menyusun RPP sebesar $0,031<0,05$ dan nilai signifikansi sikap sosial sebesar $0,006<0,05$.

\section{PENUTUP}

Hasil penelitian yang dilakukan menunjukkan bahwa terdapat pengaruh yang signifikan antara kemampuan menyusun RPP terhadap ketrampilan mengajar mahasiswa pada program PLP. Pengaruh terbesar terutama pada indikator ke $12, \quad$ yaitu langkah-langkah pembelajaran. Langkah-langkah pembelajaran sendiri berkaitan dengan metode pembelajaran. Jadi dapat dikatakan bahwa pengetahuan mahasiswa terhadap metode pembelajaran akan mempengaruhi ketrampilan mengajarnya. Karena langkah-langkah pembelajaran yang telah disusun akan membentu dalam pengkondisian kelas.

Hasil penelitian juga menunjukan adanya pengaruh signifikan antara sikap sosial terhadap ketrampilan mahasiswa. Pengaruh terbesar pada indikator ke-2 yaitu berkomunikasi secara efektif, empatik, dan santun dengan sesama pendidik, tenaga pendidik, orang tua, dan masyarakat. Kemampuan berkomunikasi ini berkaitan dengan ketrampilan bertanya, dan ketrampilan menjelaskan bagi mahasiswa. Artinya jika mahasiswa mampu berkomunikasi dengan baik maka dia akan mampu menjelaskan dengan baik. Selain itu, dengan komunikasi yang baik juga akan membantu dalam upaya bertanya-jawab kepada siswa. Dengan memiliki kemampuan bertanya yang baik, maka seorang guru akan dapat menggali sejauh mana pengetahuan yang dimiliki siswa. Sehingga dapat menentukan langkah pembelajaran yang tepat.

Berdasarkan hasil-hasil penelitian tersebut, maka untuk meningkatkan kemempuan mengajar mahasiswa atau dalam hal ini adalah calon guru, perlu ditingkatkan kemampuan menyusun RPP. Selain itu perlu ditumbuhkan pula sikap sosial pada diri mahasiswa. Karena secara langsung ketika kemampuan menyusun RPP meningkat dan sosial meningkat, maka ketrampilan mengajar pada mahasiwa juga akan meningkat. 


\section{DAFTAR PUSTAKA}

Arthur et all. (2006). Learning to Teach in the Primary School. New York: Routledge

Garth, B et all (2016). Utility of Learning Plans in General Practice Vocational Training: A MixedMethods National Study of Registrar, Supervisor, and Educator Perspectives. BMC Medical Education. 1-14

O'Sullivan, M. (2006). Lesson Observation and Quality in Primary Education as Contextual Teaching and Learning processes. International Journal of Educational Development 26 (2006) 246-260.

Permendikbud. (2016). Paeraturan Menteri Pendidikan dan Kebudayaan Republik Indonesia nomor 22 tahun 2016 Tentang Standar proses pendidikan Dasar dan menengah. Jakarta: Kementrian Pedidikan dan Kebudayaan. Simpsonet all. (1976).InfluenceofInstrument Characteristics on Student Responses in Attitude Assessment.JournalofResearchin science Teaching. Vol. 13, N0. 3. Pp 275-281 